vol. 25, $n^{\circ} 1 \mid 2021$

Varia

\title{
Barry Anthony, Murder, Mayhem and Music Hall: The Dark Side of Victorian London
}

I.B. Tauris, 2015, 244 p., ISBN: 978-1780766348

\section{Rosalind Crone}

\section{(2) OpenEdition \\ Journals}

Electronic version

URL: https://journals.openedition.org/chs/2978

DOI: $10.4000 /$ chs. 2978

ISSN: 1663-4837

\section{Publisher}

Librairie Droz

Printed version

Date of publication: 5 August 2021

Number of pages: 152-153

ISSN: $1422-0857$

\section{Electronic reference}

Rosalind Crone, "Barry Anthony, Murder, Mayhem and Music Hall: The Dark Side of Victorian London", Crime, Histoire \& Sociétés / Crime, History \& Societies [Online], vol. 25, $n^{\circ} 1$ | 2021, Online since 05 August 2021, connection on 09 November 2022. URL: http://journals.openedition.org/chs/2978 ; DOI: https:// doi.org/10.4000/chs.2978

This text was automatically generated on 9 November 2022.

All rights reserved 


\section{Barry Anthony, Murder, Mayhem and Music Hall: The Dark Side of Victorian London}

I.B. Tauris, 2015, 244 p., ISBN: 978-1780766348

Rosalind Crone

\section{REFERENCES}

Barry Anthony, Murder, Mayhem and Music Hall: The Dark Side of Victorian London, I.B. Tauris, 2015, 244 p., ISBN: 978-1780766348

1 "Rather than walk along the Strand," Barry Anthony tells us, at the end of the $19^{\text {th }}$ century "the comedian Dan Leno found it cheaper to take a cab from one end to the other", as on foot his progress was impeded by the desperate and the criminal, beggars and swindlers, on the look out for mugs who would give them some cash (p. 129). Today, you are far more likely to suffer from the intolerable traffic fumes belched out by the many cars and buses which make use of one of London's most important thoroughfares. And although it remains at the border of London's famous theatreland, there are few clues as to the Strand's disreputable and dangerous past. You would have to look hard for the blue plaque which marks the spot of the murder of William Terriss, famous actor at the Adelphi Theatre in the 1880s and 1890s. There is quite a distance physical and conceptual - between The Coal Hole at 91 Strand (which opened in the early $20^{\text {th }}$ century) and its predecessor at Fountain Court, where the self-styled "Baron" Renton Nicolson presided over re-enactments of criminal conversation trials (i.e. adultery hearings) by the infamous Judge and Jury Society.

Through the extensive use of newspaper reports and memoirs, in Murder, Mayhem and Music Hall Barry Anthony has brought the Strand of Victorian London back to life. This was a pleasure land, which fused glittering attractions with a sordid and criminal underworld, attracting men, women and even children from near and far, both catering 
to and thoroughly exploiting their dreams and desires. Anthony's book is arranged around the stories of these visitors and residents - individuals - whose lives were shaped by this fascinating mini-world that existed in central London. We meet famous actors and performers, such as Mabel Love, a teenage actress, whose advantageously timed abscondment and attempted suicide gave her career a fortuitous publicity boost, and Lottie Collins, whose famous song and dance, "Ta-ra-ra-boom-de-ay", helped to usher in the "naughty nineties". Several chapters focus on villains, including Charles le Grand, the 'psychotic blackmailer', who has more recently been suggested as a Jack the Ripper suspect, and Paul Baron, a German barber who took advantage of unsuspecting customers by pressing upon them phoney treatments and charging them a fortune for the pleasure. Providers of risque entertainments (pornographer William Dugdale and Renton Nicholson), gregarious and colourful individuals (the famous transvestites Ernest Boulton and Frederick Park), and individuals whose lives ended violently and tragically (PC George Samuel Cooke and Alexander Woodburn Heron) add further texture and range to this story.

3 Anthony argues that the lives of these characters are "worthy of re-examination as extreme representations of a disruptive counterculture that history has largely seen fit to overlook" (p. 12). For some time, historians have been alert to the existence of a dark underbelly in Victorian society and culture. The Victorians were not always prim and proper - respectability had its limits - and this was perhaps most obvious in their world of entertainment. The question that remains to be answered is the extent to which this underbelly was successfully contained. How far did this "counterculture" seep into the mainstream? Is it useful to think about the Victorians in binary terms? Were the Victorians really all that respectable? Anthony does not attempt to engage with these questions in this book, but the detail of the lives he has uncovered may provide us with some more clues. For example, a relatively high proportion of Anthony's characters came from respectable and affluent families. The degree of tolerance often shown to Boulton and Park was striking. Anthony's mini-biographies certainly highlight the diversity of Victorian lives.

The decision to focus on the lives of selected characters and their arrangement in the book also had the effect of downplaying any sense of change over time within the Victorian period. Anthony's first chapter provides an evocative account of the physical development of the Strand, especially its dramatic transformation - or destruction at the opening of the $20^{\text {th }}$ century, which is repeated at key moments in the book. There are also references to some other key moments in the regulation of social life and entertainment scattered throughout the book, but readers will need to dig hard to find them. Several important events and pieces of legislation occur around c.1870 (Licensing Act, Obscene Publications Act, the banning of cancan, the suppression of the Judge and Jury Society, the arrests of Boulton and Park). Historians have identified c.1870 as a turning point; some of the evidence presented by Anthony confirms this, other evidence here suggests some degree of continuity which needs further exploration.

5 In sum, Murder, Mayhem and Music Hall is an absorbing read. This is a different approach to exploring the dark side of Victorian London with significant potential which will hopefully be exploited and extended by historians of popular culture and crime. 


\section{AUTHORS}

ROSALIND CRONE

Open University

rosalind.crone[at]open.ac.uk 